\title{
Tekmeria
}

Vol 14 (2018)

$(2017-2018)$

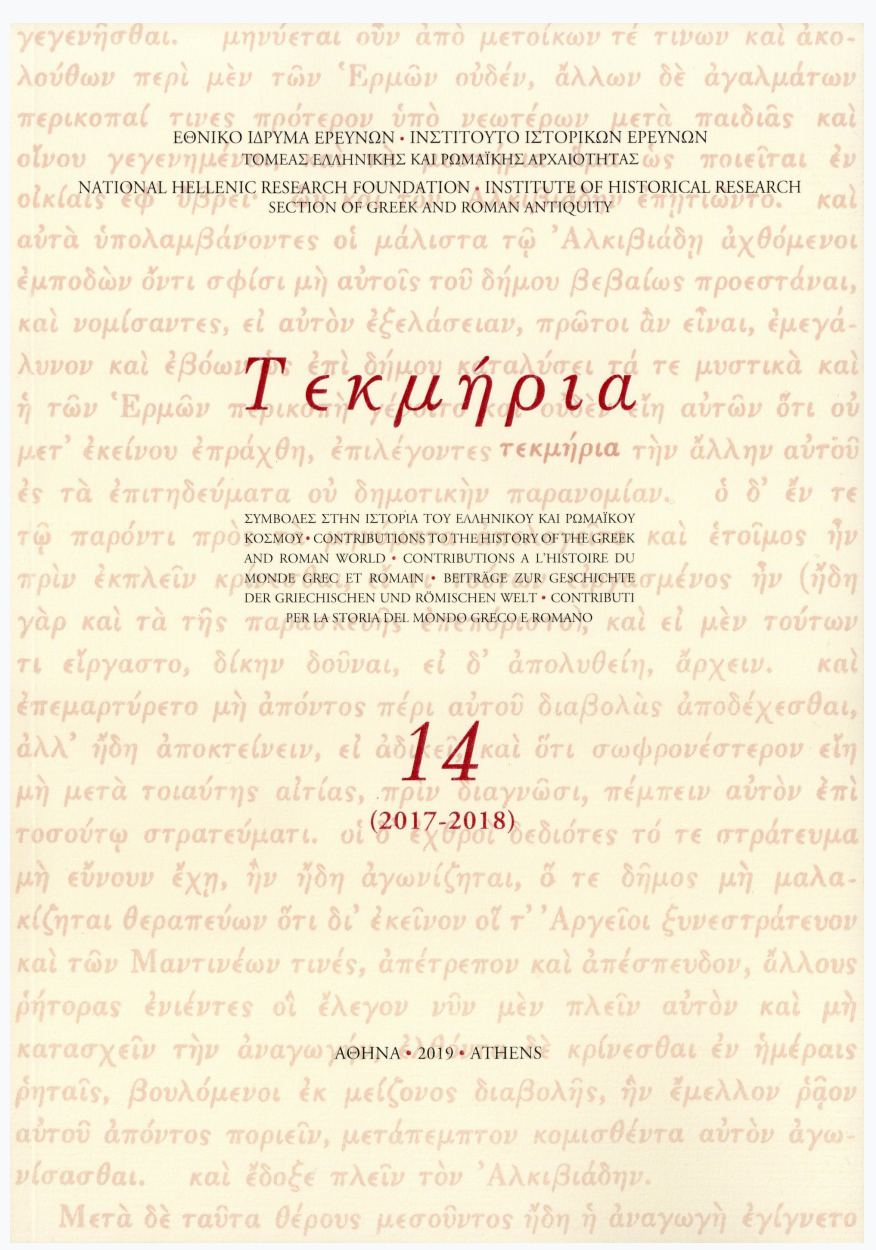

\section{Late Antique and Early Byzantine Era Inscriptions at Assos}

Tolga Özhan

doi: $10.12681 /$ tekmeria.17292

\section{Copyright $\odot$ 2018, Tolga Özhan}

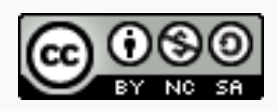

This work is licensed under a Creative Commons Attribution-NonCommercialShareAlike 4.0.

\section{To cite this article:}

Özhan, T. (2018). Late Antique and Early Byzantine Era Inscriptions at Assos. Tekmeria, 14, 47-68.

https://doi.org/10.12681/tekmeria.17292 


\section{TOLGA ÖZHAN}

\section{Late Antique and Early Byzantine Era Inscriptions at Assos}

Located in the southern Troad, Assos was founded on a slope overlooking the island of Lesbos. As one of the most opulent ancient cities of Asia Minor, Assos attracted the attention of numerous western travelers and researchers from the late 18th century onwards. ${ }^{1}$ To Assos went the first expedition of the Archaeological Institute of America when J. T. Clarke, F. H. Bacon and R. Koldewey undertook an investigation of the site from 1881 to $1883 .{ }^{2}$ After the American excavations at Assos concluded, it would be a hundred years before archaeologists started work at this significant site again. In 1981, a new archaeological dig was initiated at Assos by a team led by Ü. Serdaroğlu, who carried out excavations in various parts of the site, until he unexpectedly passed away in 2005. Assisted by a German team from 1989 to 1994 Serdaroğlu mainly concentrated on the western necropolis. The third term of excavations at Assos began under the direction of N. Arslan in 2006 and is ongoing. ${ }^{3}$ During

1. For western travelers who visited Assos, see Clarke, Bacon, Koldewey 1902, 3-4. For a brief excavation history of Assos, see Arslan, Böhlendorf-Arslan 2010, 50-53; Arslan 2010, 114-117.

2. All the epigraphic documentation of the city discovered during this three-year period was published in a paper titled Inscriptions of Assos by J. R. S. Sterrett in the first volume of Papers of the American School of Classical Studies at Athens in 1885. After the first publication, for practical reasons (praktischen Gründen) as stressed in the preface of his work, R. Merkelbach found it necessary to prepare a new epigraphic corpus of Assos, which was published in the fourth volume of the series Inschriften Griechischer Städte aus Kleinasien, I.Assos: Merkelbach, R. (ed.), Die Inschriften von Assos (IGSK 4), Bonn 1976. Mostly based on Sterrett's edition, the corpus includes 74 inscriptions with the addition of a few unpublished inscriptions from the site.

I would like to thank Nurettin Arslan for giving me permission to publish these inscriptions. My thanks also go to two anonymous reviewers for their critical corrections and additions to the paper, as well as Elias Sverkos and Christina Kokkinia for their valuable comments on the manuscript of this paper.

3. In the third excavation phase, the investigations at Assos from 2010 to 2016 were carried out in cooperation with Turkish and German archaeologists. The results 
this period of systematic excavations over more than thirty years, the archaeological fieldwork undertaken at several locations in the city have unearthed a series of new inscriptions along with other new finds. Some of these epigraphic finds appeared in the series Asia Minor Studien, including those from the excavations between 1989 and 1994. ${ }^{4}$ As a result of short-term surveys and excavations carried out in and around the site since 2006, several new inscriptions of various types (mostly funerary) dating from the Late Archaic period to the Early Byzantine period have been discovered. ${ }^{5}$ In addition, several published and unpublished inscriptions have been also identified in different parts of the city during surface investigations. This paper presents eleven of these inscriptions from the Late Antique and Early Byzantine periods.

\section{Acclamation of the Lord/Emmanouel}

A rectangular architrave block bearing four regulae with guttae used as a window lintel in the 14th-century mosque on the acropolis of Assos. ${ }^{6}$ A six-pointed star (hexagram) divides the inscription into two parts. ${ }^{7}$ It is formed of two equilateral triangles enclosed in a circle. The hexagonal shape inside the star is subdivided by intersecting lines. Due to the texture of the stone and the angle of light illuminating it, the inscription is barely legible. The length of the block is $1.825 \mathrm{~m}$, its height is $0.31 \mathrm{~m}$ and its depth is $0.33 \mathrm{~m}$. The height of the letters varies between $0.06 \mathrm{~m}$ and $0.065 \mathrm{~m}$. Date: Early Byzantine period (fig. 1).

were published in an edited book in the series of Asia Minor Studien, see Arslan, Mohr, Rheidt 2016.

4. Abmeier 1990 (SEG 40, 1112); Zelle 1990, 124 (SEG 40, 1113); Stupperich 1992, 8 and plate 6, 3; Stupperich 1993, 3, 18, 26 (SEG 43, 875); Kramer 1993 (SEG 43, 876); Kramer 2006 (SEG 56, 1361-1383). See also Cankardaş-Şenol 2007 (SEG 57, 1252-1262) and Freydank 2010, 295-305, who also lists several inscriptions discovered at the western necropolis in Assos.

5. Recent papers which include epigraphic finds from Assos are as follows: Özhan 2011 (SEG 61, 1005-1006); Arslan, Özhan 2013 (SEG 63, 1010-1012); Özhan 2015 (BE 2016, 411); Özhan 2017.

6. Note that on the same face of the mosque there are other architectural elements of the Doric order, such as triglyphs and metopes, used as spolia in the construction of the mosque. Besides these, a fragment of a templon architrave made of white marble can also be seen in the wall.

7. On the hexagram symbol in Byzantine art, see Meinardus 1976. 


$$
\text { 'E } \mu \mu \alpha^{\text {hexagram }} \nu \text { oứ } \lambda
$$

Translation: «Emmanouel»

This rectangular architrave block, which would originally have belonged to a building of the Doric order appears to have been repurposed as a door lintel in a building of the Early Byzantine period, after the inscription was carved and the hexagram was carved on it. It is not surprising to encounter the inscription

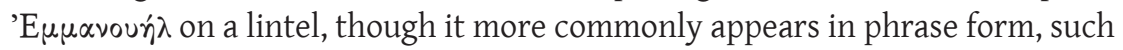

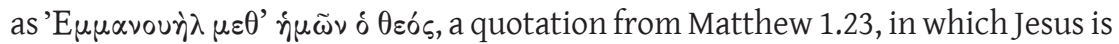
called Emmanouel, meaning "God is with us". ${ }^{8}$ The acclamation of the the Lord/ Emmanouel on the lintel at Assos should have served as apotropaic, that is to say, it was used to ward off evil from the building. ${ }^{9}$ It is highly probable that this inscribed lintel had belonged to a private house in Assos. ${ }^{10}$ Recent excavations at the lower agora inside the city unearthed the remnants of several buildings dated to the Early Byzantine period, to which this lintel may have belonged, such as the so-called "Episcopal presence-chamber" and the "Byzantine Building Complex", where one of the door lintels bears an XP Christogram. ${ }^{11}$

\section{Chrysogonos}

This inscription was found on the bedrock of the northeastern slope of the Acropolis, which was used as a quarry, as chisel traces on the bedrock indicate.

8. Cf. Feissel, Recueil 274, who lists other epigraphic attestations of the Emmanouel acclamation found on lintels from Asia Minor and Syria.

9. Cf. e.g. Ruggieri 2003, 298, 301; SEG 50, 1509; SEG 52, 1698-1703 (1703). For the function of this kind of inscriptions, including the names of God or Christ on lintels, doors or windows, see also Prentice 1906, 138. The apotropaic function of the inscription raises the question whether the hexagram accompanying the Emmanouel inscription is just a simple ornamentation or an apotropaion. Prentice (1906, 138-139) considers the possibility that some of the "disks" filled with five, six or eight-pointed stars on lintels from Syria, which appear with Christograms, the name of the God or Christ etc. may have had a protection power against evil. For the talismanic power of the hexagram symbol in the Jewish culture, see Meinardus 1976, 100, referring to E.R. Goodenough, Jewish Symbols in the Greco-Roman World, I, 68 (non vidi).

10. Cf. Ruggieri 2003, 301 n. 31, referring to PAES III, 1065, IGLS IV, 1447.

11. On these structures in the lower agora, see Arslan, Böhlendorf-Arslan, Bakan 2018, 394-395 with references to earlier excavation reports. 
It is in two lines and the initial two letters are underlined. A long cross is engraved on the right-hand side of the inscription. The height of the letters varies from $0.07 \mathrm{~m}$ to $0.135 \mathrm{~m}$. Date: 4th century AD or later (cross symbol) (fig. 2).

$$
\underline{\text { Xpuó́|rovos }}{ }^{\text {cross }}
$$

App. cr.: Chi and rho are underlined.

Translation: "Chrysogonos"

Taking into consideration the place where the inscription was carved, it is reasonable to assume that it may have been carved by a man named Chrysogonos, who worked at the stone quarry. In addition to the cross symbol, the under-

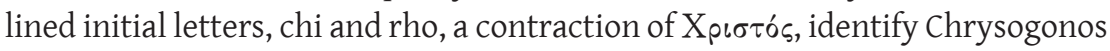
as a Christian. ${ }^{12}$

\section{Epitaph of the Gravediggers of the Great Church}

A cubic block, measuring $0.425 \mathrm{~m}$ high, $0.425 \mathrm{~m}$ wide, and $0.395 \mathrm{~m}$ deep, was found in the western necropolis of Assos in the course of excavations in 2006. The height of the letters ranges from $0.03 \mathrm{~m}$ to $0.104 \mathrm{~m}$. The text is roughly and irregularly carved. A cross is incised at the beginning of the first line. Date: 6 th century AD (terminology: Orthodox) (fig. 3).

$$
\begin{aligned}
& \text { cross Tó } \pi 0 s \\
& \delta \iota<\alpha>\varphi \varepsilon ́ p \omega \nu \\
& \delta \varepsilon x \alpha \nu \circ \tilde{\zeta} \\
& 4 \tau \tilde{\omega} \nu \omega \dot{\omega} \rho 0 \text { - } \\
& \delta \omega \xi \omega \nu \mu \varepsilon-
\end{aligned}
$$

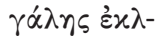

$$
\begin{aligned}
& \eta \sigma i \alpha s
\end{aligned}
$$

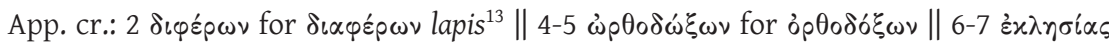
for $\dot{\varepsilon} x \varkappa \lambda \eta \sigma^{\prime} \alpha \varsigma^{14}{ }^{14}$

12. For the XP contraction, see Oikonomides 1974, 112. For Chrysogonos as a Christian name, see e.g. LGPN III.A, s.v. Xpurórovos (3) and LGPN III.B, s.v. Xpurórovos (6).

13. The form without the Alpha is epigraphically attested twice in Korykos in Ki-

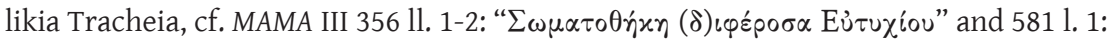

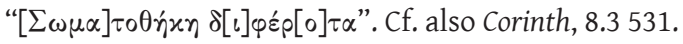

14. For the simplification of double kappa, see Gignac 1976, 160. 
Translation: "Burial spot belonging to the gravediggers of the Great Church of the Orthodox Christians."

The term dekanos in the third line means "gravedigger", a low-ranking ecclesiastical official. ${ }^{15}$ In Asia Minor, dekanoi often appear in epitaphs as the owners of the grave or as relatives of the deceased..$^{16}$ The inscription demonstrates that this stone marks the burial spot of the gravediggers of the $\mu \varepsilon \gamma \dot{\alpha} \lambda \eta \dot{\varepsilon} x \varkappa \lambda \eta$ $\sigma i \alpha$ at Assos. It also suggests that the burial spot of the gravedigger may have belonged to a burial ground reserved for dekanoi in general. Accordingly, this brings to mind the possibility that the dekanoi of Assos may have formed an occupational association in the sixth century. Since the stone is a stray find, it is difficult to localize this burial ground. The adjective óp $\theta$ ó $\delta \circ \xi \circ \varsigma$ signifies the first major polarization in Christian unity. ${ }^{17}$ By the phrase $\mu \varepsilon \gamma \dot{\alpha} \lambda \eta \eta \dot{\varepsilon} \varkappa \varkappa \lambda \eta \sigma^{\prime} \alpha$ at the end of the text, a local cathedral must have been intended, one which was located in the city or its immediate surroundings. ${ }^{18}$ Archaeological excavations at Assos have identified several churches located both inside and outside the city walls. ${ }^{19}$ Additionally, recent studies on the Ayazma Church showed the existence of an earlier church structure, probably dating to the sixth century AD, which was integrated into the later mid-Byzantine church. ${ }^{20}$ However, it is not

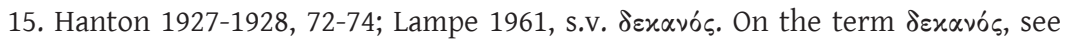
also DGE s.v. $\delta$ exavós, which gives several different meanings of the term. On church gravediggers, in general, see Hübner 2005, 34-37.

16. For the list of the inscriptions in Asia Minor recording the title dekanos, see Hübner 2005, 37.

17. Cf. Horsley 1982, 152; Horsley 1983, 111. See also McGuckin 2008, 24-25.

18. Cf. Talbot 1991, 867-868: "The expression megale ekklesia or megas naos might also be applied to some larger provincial churches, such as Hagia Sophia in Thessalonike." Ancient authors testify to the presence of local cathedrals called $\mu \varepsilon \gamma \dot{\alpha} \lambda \eta \dot{\varepsilon} \varkappa \varkappa \lambda \eta \sigma^{\prime} \alpha$ in various cities; for the list, see e.g. Downey 1959, 37 n. 2. Additionally, another church called megale ekklesia is also known in Aegina, see Vita Theodorae Thessalonicae 3. For the

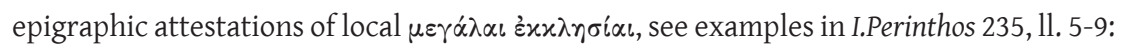

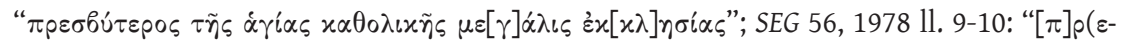

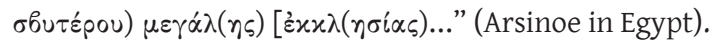

19. Arslan, Böhlendorf-Arslan 2010, 142-153; Böhlendorf-Arslan 2013, 228-230.

20. On the Ayazma church, see n. 24 below. 
possible to determine, at least for now, which church in Assos is meant by the

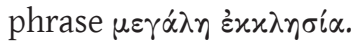

\section{Sarcophagus of the Heirs of Daniel}

Sarcophagus made of trachyte, preserving its lid, discovered during fieldwork at the western necropolis in 2006. The façade of the sarcophagus is decorated with two garlands, with pendants in the shape of a bunch of grapes. A squareshaped tabula ansata is placed between the garlands. Each semi-circular space above the garlands is decorated with a boss. The short sides are furnished with a garland and a bow-tie shaped boss decoration. The length of the façade measures $2.26 \mathrm{~m}$. The inscription is roughly carved in the tabula ansata. The height of the letters varies from $0.07 \mathrm{~m}$ to $0.09 \mathrm{~m}$. Date: Early Byzantine Period (?) (fig. 4 and fig. 4 a, detail).

$$
\begin{aligned}
& \Delta \alpha \nu i n \dot{\lambda} \text { ov }
\end{aligned}
$$

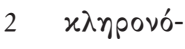

$$
\begin{aligned}
& \mu \omega \nu
\end{aligned}
$$

App. cr.: $1 \mathrm{~A}$ dash is inserted between the letters ny and iota. Another strange siglum also exists above iota. || 2 A horizontal stroke is placed above eta.

Translation: "Of Daniel's heirs."

Daniel reserved the sarcophagus for himself and his heirs, who inherited it with the rest of his estate. Before the discovery of this inscription, the Jewish name Daniel was unattested at Assos. This name also occurs at Korykos in Kilikia Tracheia, in Galatian Tavium, at Thyateira in Lydia, and at Kyzikos in Mysia. ${ }^{21}$ The majority of individuals bearing this name identified themselves as Christian by means of a cross symbol or a Christogram carved on the stones. Although there is no clear indication identifying Daniel as a Christian on the stone, it is likely that, in order to express his religious identity, the mason intended to form the contraction of I and $\mathrm{H}$ in 'I $\mathrm{I}(\sigma \circ \tilde{u} \varsigma)$ by marking the letters

21. Korykos: MAMA III 268 (with cross), 297 (with cross), 298 (the name on the stone is $\Delta \alpha v_{i}^{\prime} \lambda \circ$ ) (with cross) and $441 \mathrm{~b}$ (without any indication), Tavium: RECAM II 428 (with Christogram), Thyateira: TAM V.2 1164 (with cross), Kyzikos: Laurent 1963, 348 (with cross). Cf. Chaniotis 2002, 224 n. 53. 
iota and eta separately in the inscription. ${ }^{22}$ Alternatively, another explanation could be proposed regarding what these sigla refer to.

\section{Sarcophagus of Theoktistos}

Sarcophagus with a gabled lid, standing in the western necropolis. The façade of the sarcophagus bears a tabula ansata in the middle; on each side of the tabula ansata hangs a thin, flat garland with a pendant. Each semi-circular space above the garlands is decorated with a boss. Garlands with a pendant and a boss decoration above embelish the short left and right sides. The back of the sarcophagus is decorated in the same manner as the façade, except for the tabula ansata itself, which is square. The front side measures $2.975 \mathrm{~m}$. The height of the letters varies between $0.085 \mathrm{~m}$ and $0.14 \mathrm{~m}$. Date: 4 th century AD or later (cross symbol) (fig. 5 and fig. 5a, detail).

cross $\Theta \varepsilon o x \tau i ́ \sigma \tau o v$

$\Lambda$ IMA

App. cr.: 1 Upsilon is carved to the lower right of omikron, where the tabula ansata joins the garland.

Translation: "Of Theoktistos."

Theoktistos was a common Christian name that was previously unattested in Assos. ${ }^{23}$ The second line possibly bears a patronymic, which is open to debate. The first letter is uncertain; it may be a delta (see the detailed photo), in which case it can be read as $\Delta \iota \mu \tilde{\alpha}$, an iotacism for $\Delta \eta \mu \tilde{\alpha}$.

\section{Sarcophagus Inscriptions from the Ayazma Church}

The inscriptions presented below (nos. 6-10) come from the floor of Ayazma Church, dated to the mid-Byzantine period, which was built on the remnants

22. For the IH contraction, see Oikonomides 1974, 72.

23. For the name Theoktistos, see Cumont 1895, 262; Masson 1997, $618=$ Masson 2000, 283; Kajanto 1963, 103: "for the pagan interpretation of the rare Theoctistus, see SICV 152 idem 204". See also Kajava 2004, 18. For the epigraphic attestation of these names in Asia

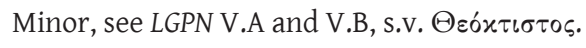


of a sixth century church. It lies on the podium of two Hellenistic monumental

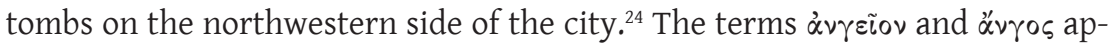
pearing in two inscriptions (nos. 6 and 7) clearly show that all the rectangular slabs paving the floor were produced by cutting out the long sides of the sarcophagi. ${ }^{25}$

\section{Bas(s)os}

Height $0.592 \mathrm{~m}$, width $2.045 \mathrm{~m}$. The height of the letters varies between $0.05 \mathrm{~m}$ and $0.07 \mathrm{~m}$. Date: 3rd or 4th century $\mathrm{AD}$ (?) (fig. 6).

$$
\begin{aligned}
& \text { OYTON tò àv- }
\end{aligned}
$$

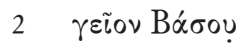

App. cr.: 1 Note that the left hand-side of the inscription is intact. The form of the upsilon is distinctively different from the upsilon at the end of the second line. Here,

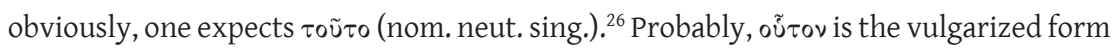

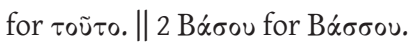

Translation: "(This is) the sarcophagus of Bas(s)os."

This is the first epigraphic attestation in Assos of the term $\dot{\alpha} \nu \gamma \varepsilon i o v$ (in other inscriptions from Asia Minor the term is spelled $\alpha \gamma \gamma \varepsilon i \tilde{o v})$, meaning sarcophagus, which appears in various regions of Asia Minor and frequently in Lycia and Pamphylia. ${ }^{27}$

\section{Eutychianos}

Height $0.61 \mathrm{~m}$, width $1.916 \mathrm{~m}$. The height of the letters varies from $0.05 \mathrm{~m}$ to $0.105 \mathrm{~m}$. Date: 3 rd or 4th century AD (?) (fig. 7).

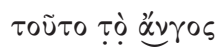

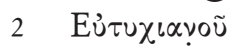

24. For recent archaeological research on the Ayazma Church and other churches at Assos, see Böhlendorf-Arslan 2013, 228-238; Böhlendorf-Arslan 2016.

25 . On the reuse by Christians of materials from funerary monuments as construction materials, see Coates-Stephens 2003, 350-352.

26. Cf. inscription no. 7 in this paper.

27. See Kubinska 1968, 40. See also Stephanidou-Tiveriou 2014, 93, 99. 
App. cr.: 1 Alpha and ny in ligature.

Translation: "This is the sarcophagus of Eutychianos."

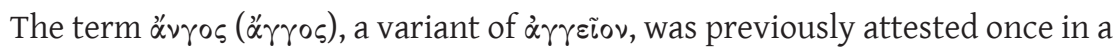
sarcophagus inscription from Assos. ${ }^{28}$ This term is also found in Lycian Olympos and Selge in southern Pisidia. ${ }^{29}$

Eutychianos was a common name in Asia Minor in the Roman Imperial period, ${ }^{30}$ but was unattested in Assos prior to the discovery of this inscription.

\section{Onesimos}

Height $0.572 \mathrm{~m}$, width $2.177 \mathrm{~m}$. The height of the letters measures $0.086 \mathrm{~m}$ and $0.187 \mathrm{~m}$. A cross is carved at the beginning of the inscription. Date: 4 th century $\mathrm{AD}$ or later (cross symbol) (fig. 8).

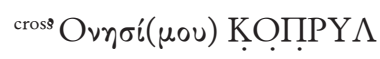

As frequently seen in sarcophagus inscriptions at Assos belonging to Late Antiquity and the Byzantine period, recording the deceased's name in the genitive case, it is highly probable that $\mathrm{ONH} \Sigma \mathrm{I}$ was the abbreviated form of the genitive

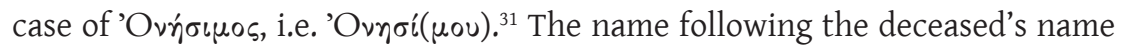
should be a patronymic, but the name is problematic. The first three letters following the iota are doubtful because of the crack in the middle of the stone and the spoilt surface on that spot. The first dubious letter seems like a kappa with curved oblique strokes in the form of lunate sigma (C). The omikron following the kappa is uncertain; there may or may not be a minuscule $\mathrm{O}$ inserted between the strokes of the kappa. The third letter looks like a pi or an eta. The first possible reading seems to be KỌฺPY $\Lambda$, as given in the transcription, which would be the abbreviated form of $\operatorname{Ko\pi \rho u} \lambda(\lambda \circ u)$, a name that frequently

\section{I.Assos 72a. Cf. Kubinska 1968, 46.}

29. Olympos: TAM II.3 1164 (cf. Kubinska 1968, 46), Selge: I.Selge 66.

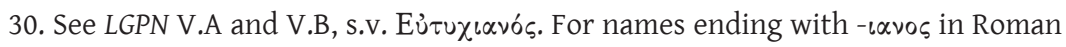
Asia Minor, see Corsten 2010. See also Sverkos 2010.

31. Cf. I.Assos 69, 72b and inscriptions nos. 4, 5, 9 and 10 in this paper. For the abbre-

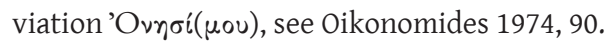


appears in Macedonia. ${ }^{32}$ Otherwise, it should be read as KHPY $\Lambda$, which is the abbreviated form of $\operatorname{K} \eta \underline{\rho} \lambda_{\lambda}(\lambda \circ u)$, an iotacism for $\operatorname{Kupí\lambda }(\lambda \circ u)$.

Translation: "OfOnesimos, son of Kopryllos/Kyrillos."

\section{Anastasios}

Height $0.47 \mathrm{~m}$, width $1.985 \mathrm{~m}$. The height of the letters varies from $0.067 \mathrm{~m}$ to 0.079 m. Date: Probably 5th-6th century AD (because of the ecclesiastical title presbyteros) (fig. 9).

$$
\begin{aligned}
& \text { 'Ạ } \nu \alpha \sigma \tau \alpha \sigma i ̣ \text { ơ }
\end{aligned}
$$

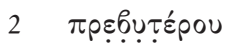

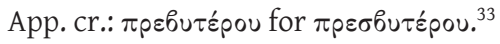

Translation: "Of presbyteros Anastasios."

In addition to presbyteros Anastasios, presbyteroi Helladios and Loukianos are also known from two funerary inscriptions at Assos dating to the fifth-sixth century AD. ${ }^{34}$

\section{Eugenios}

Height $0.52 \mathrm{~m}$, width $2.04 \mathrm{~m}$. The height of the letters varies from $0.067 \mathrm{~m}$ to 0.106 m. Date: 4 th century AD or later (based on - เo suffix) (fig. 10).

$$
\text { Eủrevíou }
$$

Translation: "Of Eugenios."

This is the first occurrence of the name Eugenios in Assos. ${ }^{35}$

32. For this name in Macedonia, see Daux 1975, 168 n. 93. See also LGPN IV, s.v. Kó$\pi \rho \Delta \lambda \lambda$ ५. For attestations of this name in the Byzantine period, see e.g. Feissel, Recueil, 122. For the name Kó $\pi \rho \nu \lambda \lambda \circ \varsigma$ and other related names, see Masson 1996, 147-150 = Masson 2000, 260-263. See also Pomeroy 1986.

33. For the omission of sigma before a labial, see Gignac 1976, 130.

34. I.Assos 35a and 72b. Cf. Destephen 2008, 436 and 625. For the name Anastasios, see Kajanto 1963, index s.v. Anastasius. In general, on presbyteroi in Asia Minor, see Hübner 2005, 56-59.

35. For occurences of this name in Asia Minor, see LGPN V.A and V.B, s.v. Eủrévıos; 


\section{Fragment of a Sarcophagus Inscription}

A fragmentary inscription on a fragment of a sarcophagus found in the western necropolis. Height: $0.49 \mathrm{~m}$, width: $0.80 \mathrm{~m}$, depth: $0.11 \mathrm{~m}$. The height of the letters varies from $0.09 \mathrm{~m}$ to $0.14 \mathrm{~m}$. Date: Early Byzantine period (?) (fig. 11).

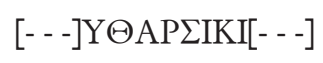

This fragment belongs to a sarcophagus inscription. It can be read as $\theta \dot{\alpha} \rho \sigma \iota$, an expression of encouragement addressed to the dead, which may have been followed by the name of the deceased. However, this expression is very uncommon in the funerary inscriptions of Asia Minor and the only epigraphic attestation of the expression is found in a bilingual epitaph from Phrygian Apameia; otherwise, it is unattested in Asia Minor. ${ }^{36}$ It seems more probable to me that the surviving part bears the name Tharsikios, which possibly stands as a patronymic, i.e. $\Theta \alpha \rho \sigma u x[0 v] .^{37}$ The missing left part should then bear the name of the owner of the sarcophagus in the genitive case, i.e. [-- o $] \nu \Theta \alpha \rho \sigma \iota x i[0 u] .^{38}$

Tolga Özhan

Çanakkale Onsekiz Mart University email: tolgaozhan@comu.edu.tr

Chaniotis 2002, 203. For the name Eugenios, see Kajanto 1963, 26, 70, 73, 74 and 83. For names ending with -ıos, see Kajanto 1982, 115-118.

36. SEG 37, 1103.

37. For the name Tharsikios, which possibly originated from the name Tharsus, see Kajanto 1963, 77 and 85. This name is also epigraphically attested in Mytilene on the island of Lesbos, see Kaldellis, Efthymiadis 2010, 64.

38. Cf. inscription no. 8 in this paper. 


\section{Summary}

In this paper, eleven new inscriptions are presented, which were found between 1981 and 2017 at Assos in the southern Troad, Asia Minor. Funerary inscriptions that can be dated to the Late Antique and Byzantine periods constitute the majority of the inscriptions found during the period defined above. The first inscription, carved on a lintel, is an acclamation of the Lord/ Emmanouel. The personal name Chrysogonos in the second inscription may have been the name of a stonecutter who worked in the quarry. The third inscription is the epitaph of the gravediggers of the Orthodox "Great Church". By the phrase "Great Church" ( $\mu \varepsilon \gamma \alpha \dot{\lambda} \lambda \eta \dot{\varepsilon} \varkappa \varkappa \lambda \eta \sigma i \alpha)$, a cathedral must have been intended, located inside the city or its immediate surroundings. The fourth inscription presented here is the sarcophagus inscription of the heirs of an individual called Daniel. The fifth is the sarcophagus inscription of Theoktistos. The inscriptions nos. 6-10 from the floor of Ayazma Church include several sarcophagus inscriptions: No. 6 is of Bas(s)os, no. 7 is of Eutychianos, and no. 8 is of Onesimos, whose father's name is uncertain due to a crack and damage on the surface of the stone. No. 9 is the sarcophagus of presbyter Anastasios, and no. 10 is the sarcophagus of Eugenios. The eleventh inscription is a fragmentary sarcophagus inscription. 


\section{Bibliography}

Abmeier, A. 1990. "Neue Grabinschriften”, in Ü. Serdaroğlu, R. Stupperich, E. Schwertheim (eds.), Ausgrabungen in Assos (AMS 2). Bonn, 23-28.

Arslan, N. 2010. “Troas Bölgesi'ndeki Taşın Hayat Verdiği Kent Assos: 18812009 Yılları Arasında Kazılara Genel Bakış”, Colloqium Anatolicum 9, 113-139.

Arslan, N., Böhlendorf-Arslan, B. 2010. Living in the Rocks. Assos. An Archaeological Guide. İstanbul.

Arslan, N., Böhlendorf-Arslan, B., Bakan, C. 2018. “Assos Kazı 2016 Yılı Çalışmaları”, in 39. Kazı Sonuçları Toplantısı 3. Cilt, 22-26 Mayıs 2017. Bursa, 389-403.

Arslan, N., Mohr, E.-M., Rheidt, K. 2016. Assos. Neue Forschungsergebnisse zur Baugeschichte und Archäologie der südlichen Troas (AMS 78). Bonn.

Arslan, N., Özhan, T. 2013. "Tiyatro Yazıtları Işı̆̆ında Assos’ta Zanaatkârlar”, Belleten 77/278, 73-83.

Böhlendorf-Arslan, B. 2013. "Forschungen zum spätantiken und byzantinischen Assos", in N. Arslan, K. Rheidt (eds.), Assos. Bericht über die Ausgrabungen und Forschungen zur Stadtentwicklungsgeschichte 2006 bis 2011, AA 1, 228-238.

Böhlendorf-Arslan, B. 2016. "Die Ayazmakirche in Assos: Lokales Pilgerheiligtum und Grabkirche", in N. Arslan, E.-M. Mohr, K. Rheidt (eds.), Assos. Neue Forschungsergebnisse zur Baugeschichte und Archäologie der südlichen Troas (AMS 78). Bonn.

Cankardaş-Şenol, G. 2007. "Stamped Amphora Handles from Assos-Turkey", Arkeoloji Dergisi 10, 109-131.

Chaniotis, A. 2002. "The Jews of Aphrodisias. New Evidence and Old Problems", SCI 21, 209-242.

Clarke, J.T., Bacon, F.H., Koldewey, R. 1902. Investigations at Assos. Drawings and Photographs of Building and Objects Discovered during the Excavations of 1881-1882-1883. London.

Coates-Stephens, R. 2003. "Attitudes to Spolia in Some Late Antique Texts", in: L. Lavan, W. Bowden (eds.), Theory and Practice in Late Antique Archaeology. Leiden - Boston 2003, 341-358.

Corsten, T. 2010. "Names in -IANO $\Sigma$ in Asia Minor. A Preliminary Study", in R.W.V. Catling, F. Marchand (eds.), Onomatologos. Studies in Greek Personal Names Presented to Elaine Matthews. Oxford, 456-463.

Cumont, F. 1895. "Les inscriptions chrétiennes de l'Asie Mineure", Mélanges d'archéologie et d'histore 15, 245-299. 
Daux, G. 1975. "Notes de lecture”, BCH 99, 145-171.

Destephen, S. (ed.) 2008. Prosopographie chrétienne du Bas-Empire, 3. Prosopographie du diocèse d'Asie (325-641). Paris.

Downey, G. 1959. "The Name of the Church of St. Sophia in Constantinople", HThR 52 1959, 37-41.

Freydank, J. 2010. Die Westtor-Nekropole von Assos in klassischer und hellenistischer Zeit (Universität Mannheim, Unpublished PhD Dissertation, Mannheim).

Gignac, F.T. 1976. A Grammar of the Greek and Roman Papyri of the Roman and Byzantine Periods, I, Phonology. Milan.

Hanton, E. 1927-1928. "Lexique explicatif du recueil des inscriptions grecques chrétiennes d'Asie Mineure", Byzantion 4, 53-136.

Horsley, G.H.R. (ed.) 1982. New Documents Illustrating Early Christianity. A Review of the Greek Inscriptions and Papyri Published in 1977, II. North Ryde.

Horsley, G.H.R. (ed.) 1983. New Documents Illustrating Early Christianity. A Review of the Greek Inscriptions and Papyri Published in 1978, III. North Ryde.

Hübner, S. 2005. Der Klerus in der Gesellschaft des spätantiken Kleinasiens. München.

Kajanto, I. 1963. Onomastic Studies in the Early Christian Inscriptions of Rome and Carthage. Helsinki.

Kajanto, I. 1982. The Latin Cognomina. Rome.

Kajava, M. 2004. “Theoktistos”, Arctos 38, 17-25.

Kaldellis, A., Efthymiadis, S. (eds.) 2010. The Prosopography of Byzantine Lesbos, 284-1355 A.D. A Contribution to the Social History of the Byzantine Province (Veröffentlichungen zur Byzanforschung 22). Vienna.

Kramer, N. 1993. “Amphorenstempel”, in: Ü. Serdaroğlu, R. Stupperich (eds.) Ausgrabungen in Assos 1991 (AMS 10). Bonn, 187-199.

Kramer, N. 2006. "Neue Amphorenstempelfunde aus Assos", in: R. Stupperich (ed.), Ausgrabungen in Assos 1993 (AMS 57). Bonn, 113-125.

Kubinska, J. 1968. Les Monuments Funéraires dans les Inscriptions grecques de l'Asie Mineure. Warsaw.

Lampe, G.W.H. 1961. A Patristic Greek Lexicon. Oxford.

Laurent, V. (ed.) 1963. Le corpus des sceaux de l'empire byzantin, V.1. L'Église. Paris.

Masson, O. 1996. "Nouvelles notes d'anthroponymie grecque", ZPE 112, 143-150.

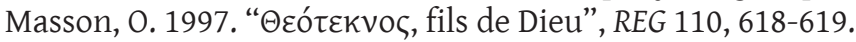

Masson, O. 2000. Onomastica Graeca Selecta, III. Geneva.

McGuckin, J.A. 2008. The Orthodox Church. An Introduction on Its History, Doctrine, and Spiritual Culture. Oxford.

Meinardus, O.F.A. 1976. "The Hexagram or the Magen David in Byzantine Art”,

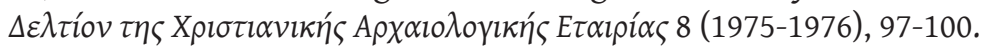


Oikonomides, A.N. 1974. Abbreviations in Greek Inscriptions. Papyri, Manuscripts, and Early Printed Books. Chicago.

Özhan, T. 2011. “Two Inscribed Pedestals from Assos”, EA 44, 170-172.

Özhan, T. 2015. "Five Fragmentary Inscriptions from Assos”, Gephyra 12, 179189.

Özhan, T. 2017. “A New Honorary Inscription from Assos”, Archivum Anatolicum 11, 71-76.

Pomeroy, S.B. 1986. "Copronyms and the Exposure of Infants in Egypt", in: R.S. Bagnall, A.A. Schiller, W.V. Harris (eds.), Studies in Roman Law. In Memory of A. Arthur Schiller. Leiden, 147-162.

Prentice, W.K. 1906. "Magical Formulae on Lintels of the Christian Period in Syria”, AJA 10/2, 137-150.

Ruggieri, V. 2003. "EMMANOYHム: Variazioni Semantiche”, Römische Historische Mitteilungen 45, 287-303.

Stephanidou-Tiveriou, T. (ed.) 2014. Die Lokalen Sarkophage aus Thessaloniki. Mit epigraphischen Beiträgen von Pantelis Nigdelis (Sarkophag-Studien 8). Ruhpolding.

Stupperich, R. 1992. "Zweiter Vorbericht über die Grabung in der Westtor-Nekropole von Assos im Sommer 1990”, in: Ü. Serdaroğlu, R. Stupperich, Ausgrabungen in Assos 1990 (AMS 5). Bonn, 1-31.

Stupperich, R. 1993. "Dritter Vorbericht über die Grabung in der Westtor-Nekropole von Assos im Sommer 1991", in Ü. Serdaroğlu, R. Stupperich (eds.) Ausgrabungen in Assos 1991 (AMS 10). Bonn, 1-35.

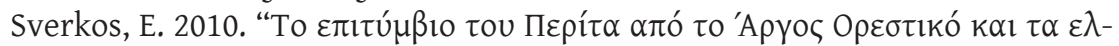

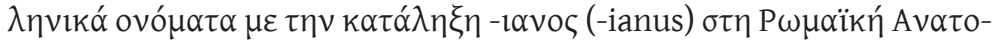

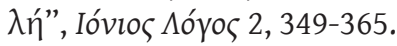

Talbot, A.M. 1991. "Great Church”, in A.P. Kazhdan (ed.), The Oxford Dictionary of Byzantium, 2, 867-868.

Vita Theodorae Thessalonicae $=$ Ed. and trans. in Russian by Bishop Arsenij, Zitie $i$ podvigi sv. Feodory Solunskoj. Juriev 1899.

Zelle, M. 1990. “Terra Sigillata”, in Ü. Serdaroğlu, R. Stupperich, E. Schwertheim (eds.), Ausgrabungen in Assos (AMS 2). Bonn, 97-125. 
Tolga ÖZHAN

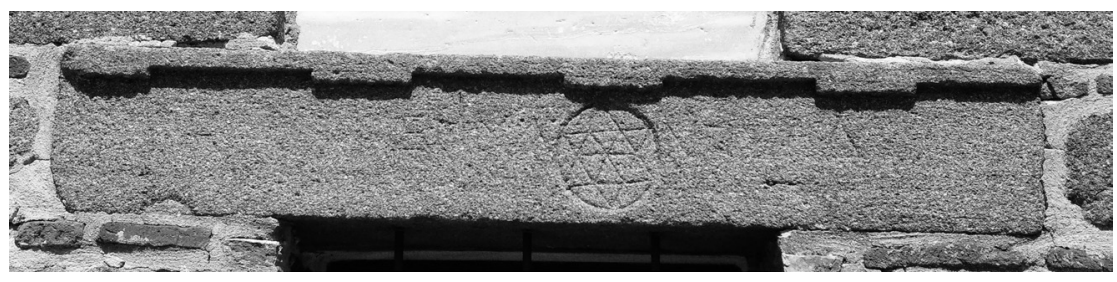

Fig. 1. No. 1: Acclamation of the Lord/Emmanouel on architrave block (Photo by the author).

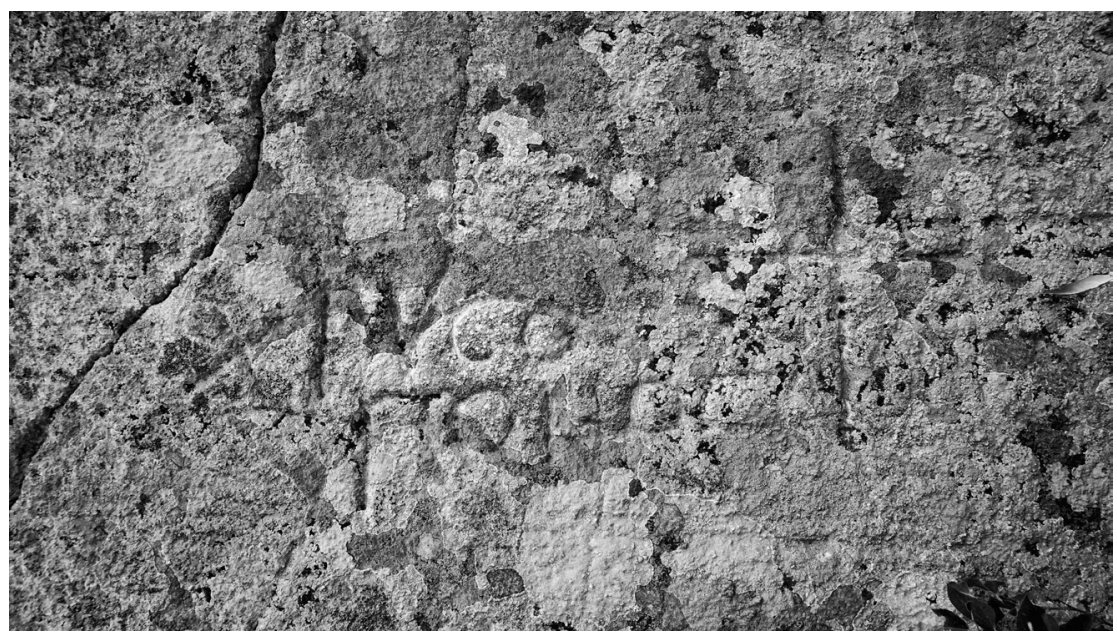

Fig. 2. No. 2: Inscription on the bedrock (Photo by the author). 
Late Antique and Early Byzantine ERa Inscriptions at Assos

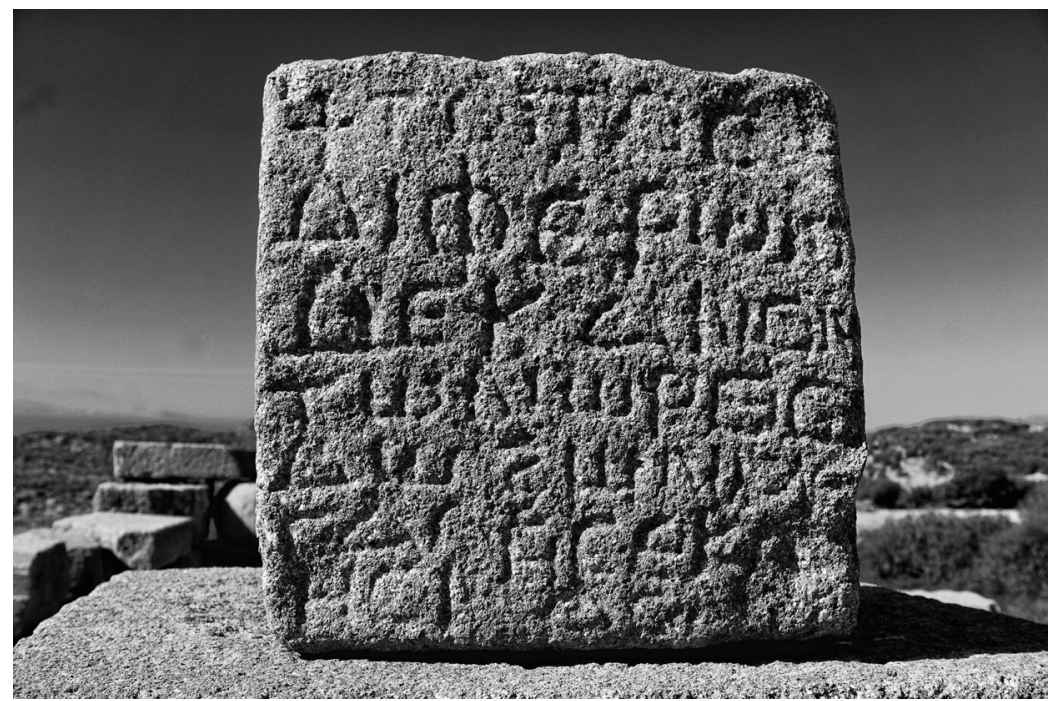

Fig. 3. No. 3: Epitaph of the gravediggers of Great Church

(Photo by the author). 


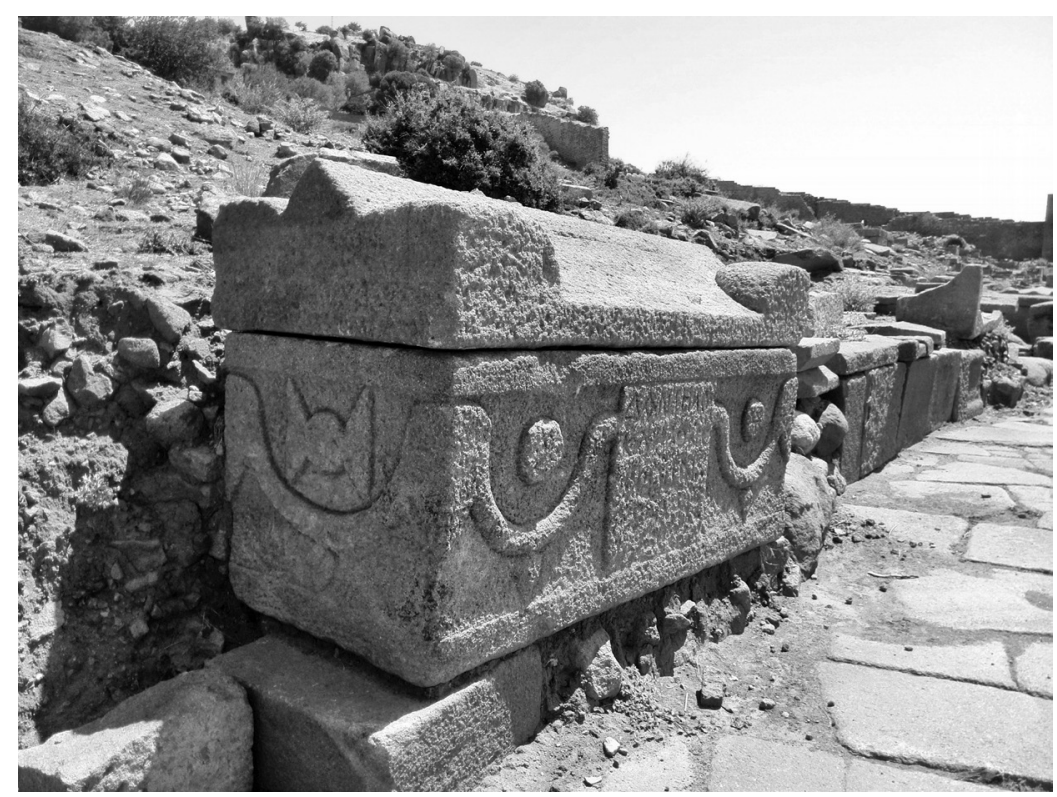

Fig. 4. No. 4: Sarcophagus of the heirs of Daniel (Photo by the author).

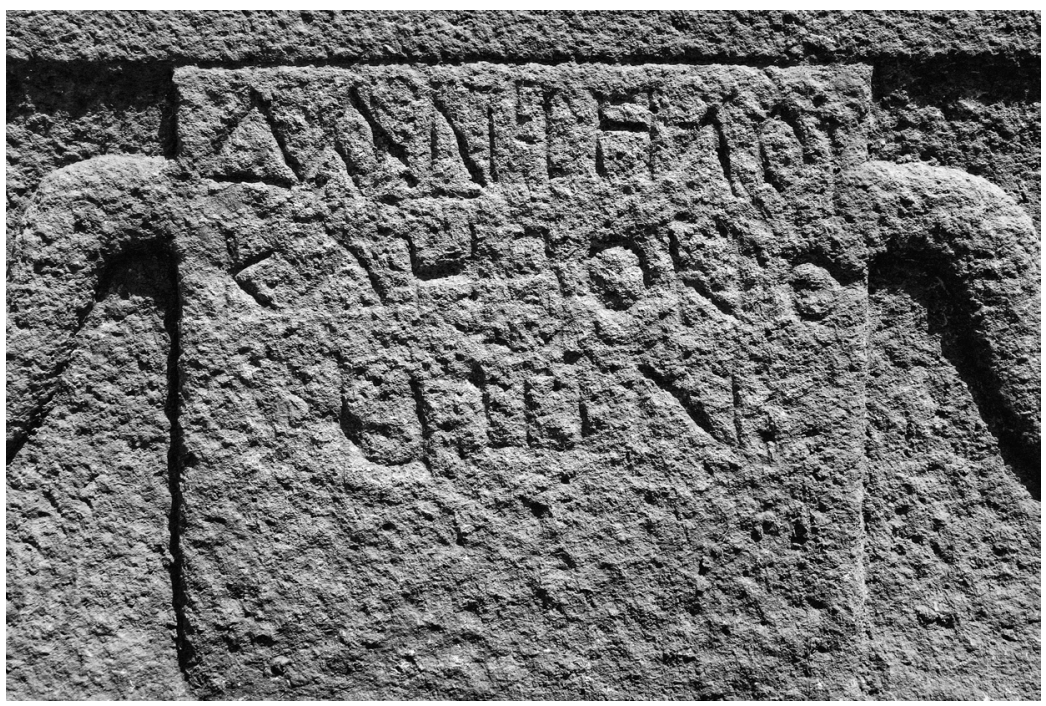

Fig. 4a. No. 4: Detail of the tabula ansata (Photo by the author). 


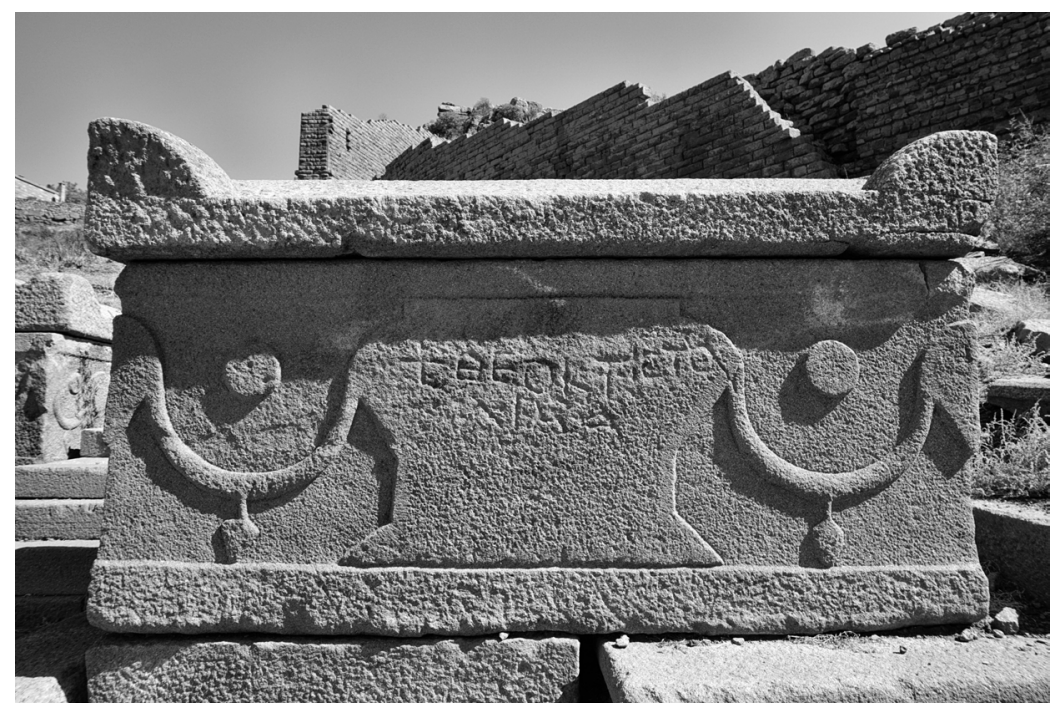

Fig. 5. No. 5: Sarcophagus of Theoktistos (Photo by the author).

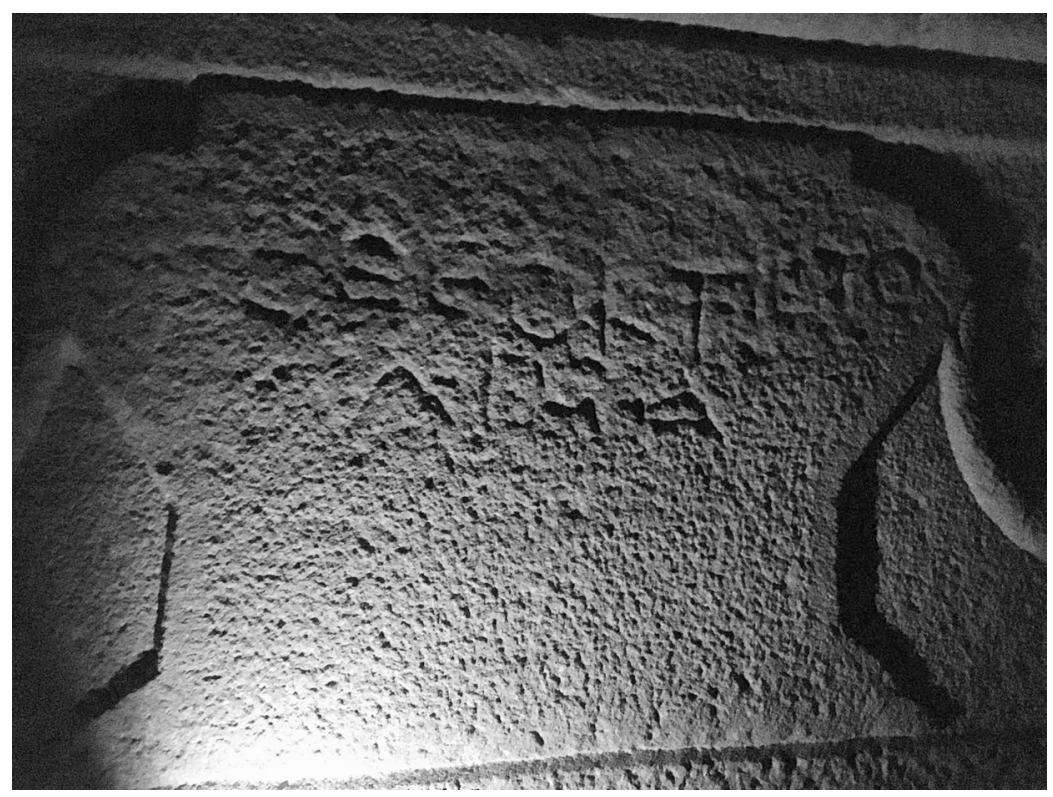

Fig. 5a. No. 5: detail (Photo: S. Akçiçek). 


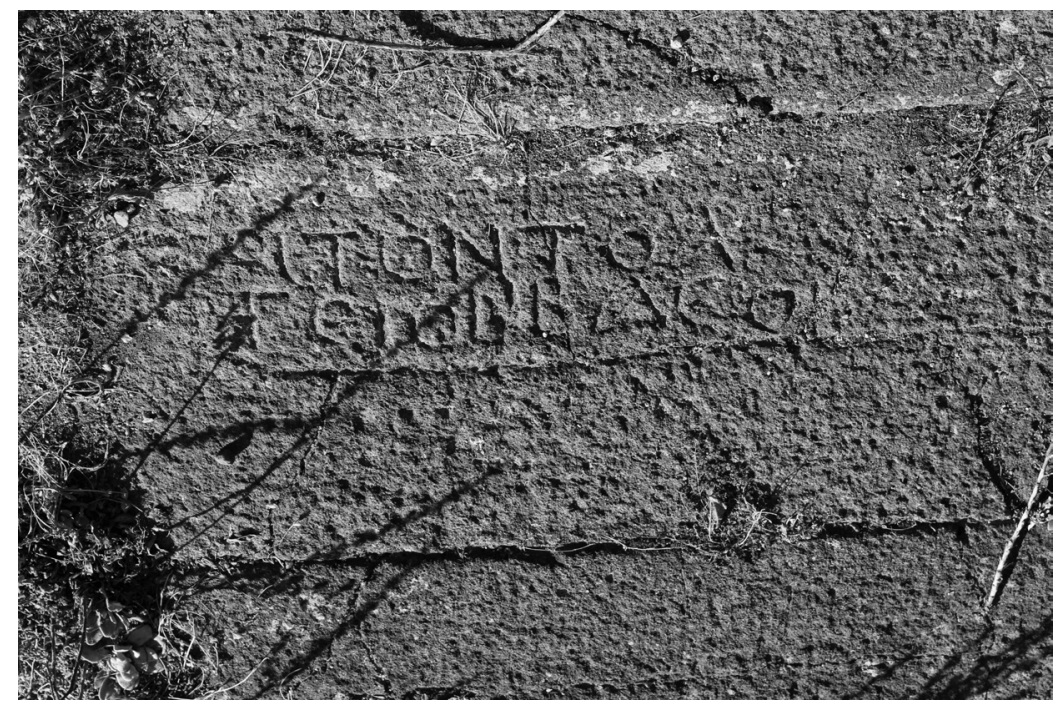

Fig. 6. No. 6: Sarcophagus inscription of Bassos (Photo by the author).

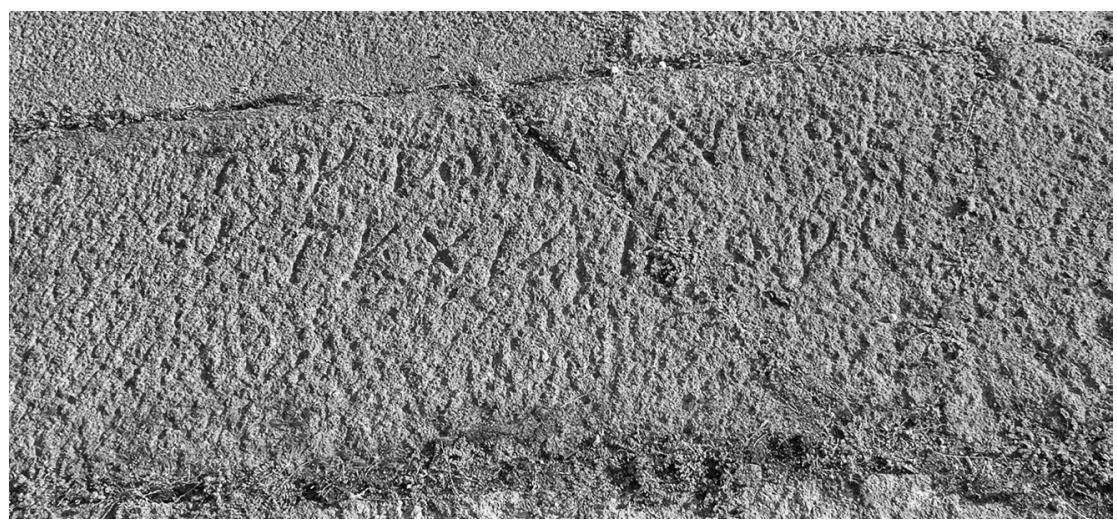

Fig. 7. No. 7: Sarcophagus inscription of Eutychianos (Photo by the author). 


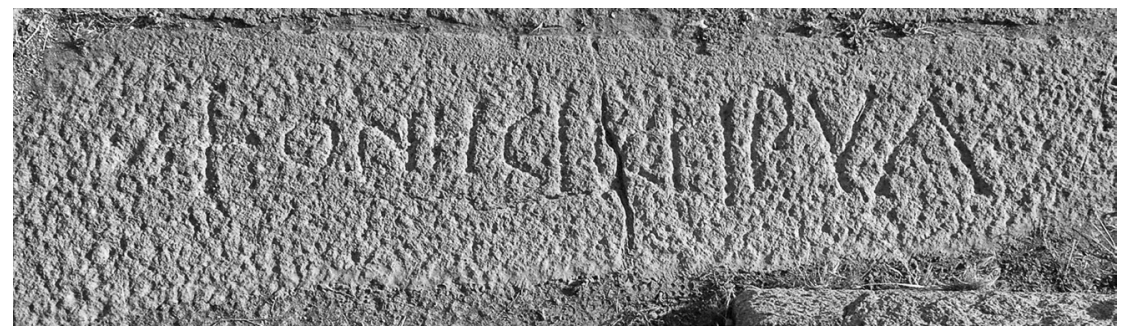

Fig. 8. No. 8: Sarcophagus inscription of Onesimos (Photo by the author).

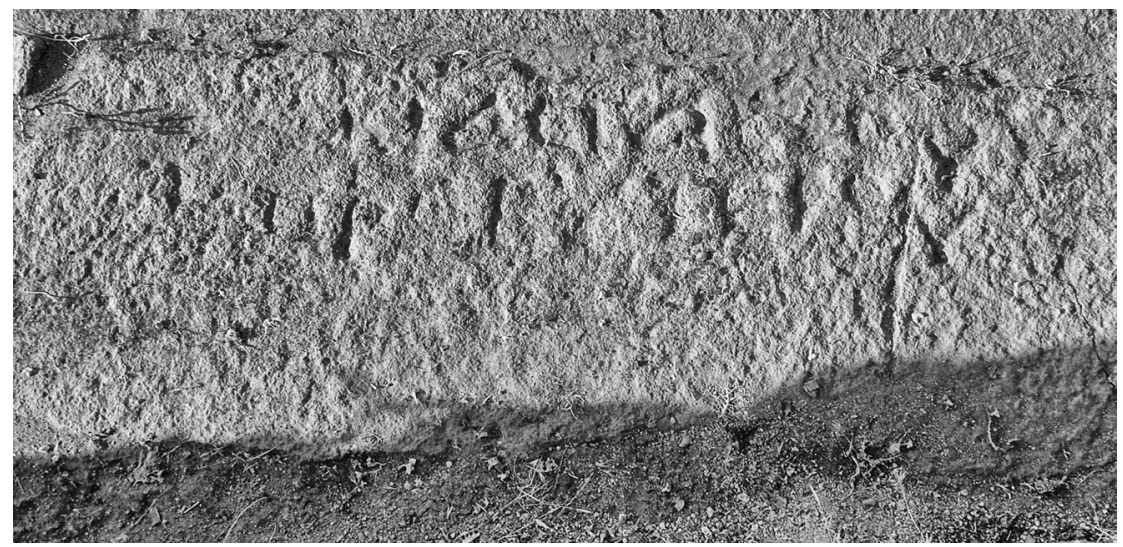

Fig. 9. No. 9: Sarcophagus inscription of Anastasios (Photo by the author). 


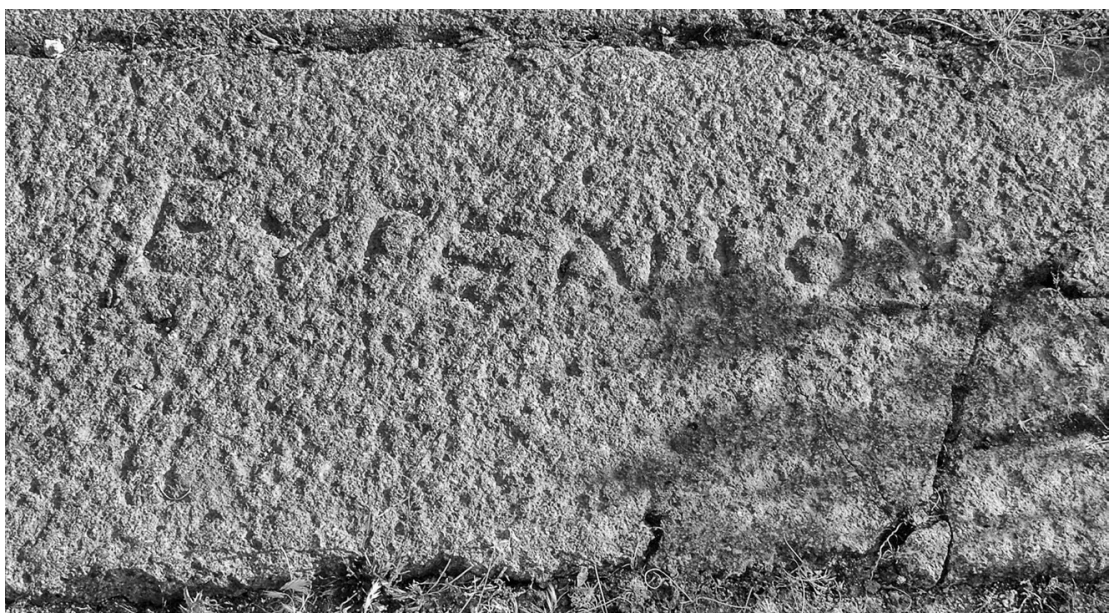

Fig. 10. No. 10: Sarcophagus inscription of Eugenios (Photo by the author).

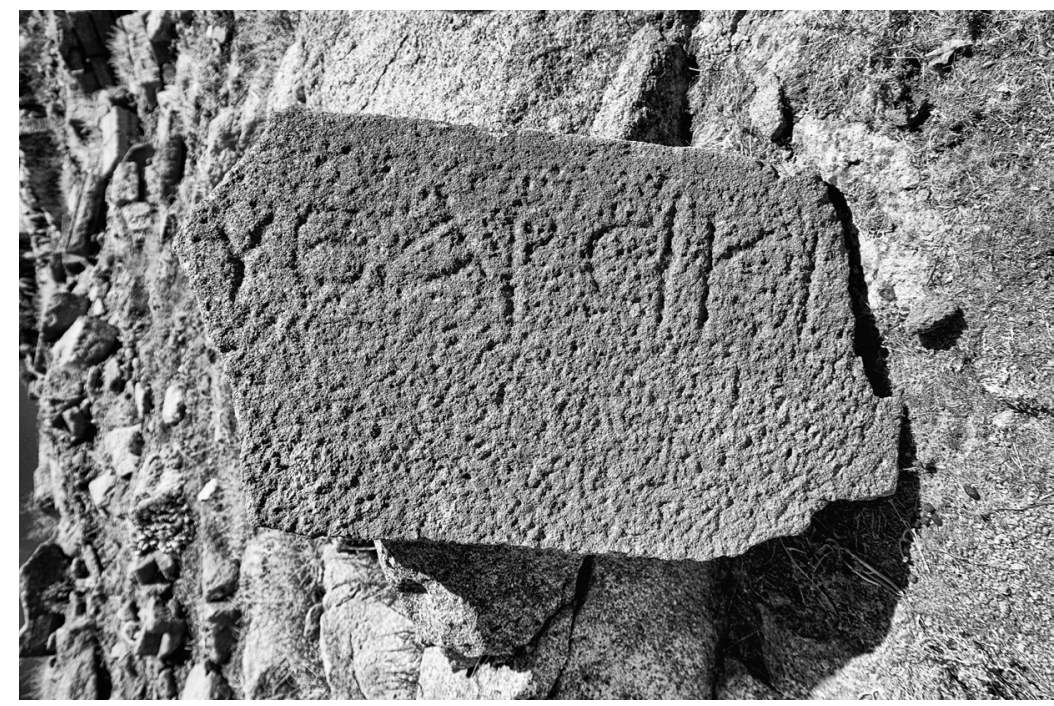

Fig. 11. No. 11: Fragment of Sarcophagus inscription (Photo by the author). 